African Crop Science Journal by African Crop Science Society is licensed under a Creative Commons Attribution 3.0 Uganda License. Based on a work at www.ajol.info/ and www.bioline.org.br/cs DOI: http://dx.doi.org/10.4314/acsj.v23i4.1

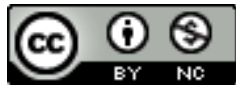

\title{
DISCRIMINATING PHENOTYPIC MARKERS REVEAL LOW GENETIC DIVERSITY IN SPIDER PLANT
}

\author{
P. WENYIKA, E. GASURA, N.M. KAFESU, M. GOSS, A. MATIKITI and G. KUJEKE \\ Department of Crop Science, University of Zimbabwe, P. O Box 167, Mt Pleasant, Harare, Zimbabwe \\ Corresponding author: egasura@agric.uz.ac.zw, gasurae@yahoo.com
}

(Received 19 August, 2015; accepted 25 November, 2015)

\begin{abstract}
Traditional vegetables such as spider plant (Cleome gynandra L.) have better nutritional and health benefits. The aim of this study was to determine the extent of genetic diversity of spider plant genotypes based on phenotypic markers and understand its implications in germplasm utilisation in Zimbabwe. Eighteen genotypes collected from across Zimbabwe were evaluated for phenotypic traits. There were no significant differences $(\mathrm{P}<0.05)$ in days to flowering, number of branches, fresh and dry mass, pod number, pod length and stem height. Variance components due to error were higher than genotypic variance components for all quantitative traits, resulting in low broad sense heritability estimates, $<39 \%$. Stem colour, pod lining, number of leaf loblets, pod shape and colour, and stem pubescence showed variations. Hierarchical cluster analysis showed $30 \%$ dissimilarity among genotypes. At $85 \%$ similarity level, there were four clusters and one of the clusters had eleven out of eighteen genotypes. The results showed low genetic diversity of spider plant in the country. Most agronomic traits could have been affected by directional selection arising from farmers preferences. Some selectively neutral descriptor traits such as colour of the stem and pods, leaf loblets number, pod lining and pod shape can be used in characterising and distinguishing spider plant genotypes.
\end{abstract}

Key Words: Cleome gynandra, descriptor traits, Zimbabwe

\section{RÉSUMÉ}

Les légumes traditionnels tels que la plante arraignée (Cleome gynandra L.) ont de bonnes propriétés nutritionnelles. L'objectif de cette étude était de déterminer l'envergure de la diversité génétique des génotypes de la plante arraignée, et ceci en se basant sur des marqueurs phénotypiques en vue de l'utilisation des germplasm au Zimbabwé. Dix-huit génotypes collectés dans différents endroits au Zimbabwé ont été évalués suivant des traits phénotypiques. Il n'y avait pas de différence significative $(\mathrm{P}<0.05)$ entre les dates de floraison, nombres de branches, masse fraîche et sèche, nombre de fruit, longueur du fruit et taille de la tige. La composante de variance liée à l'erreur expérimentale était plus élevée que la composante de variance génotypique pour tous les traits quantitatifs mesurés, ceci résulte en une valeur faible d'héritabilité au sens large, $<39 \%$. La couleur de la tige, l'aspect du fruit, le nombre de lobules foliaires, la forme et la couleur du fruit et la pubescence de la tige ont montré une variabilité. La classification numérique a montré 30\% de dissimilarité entre les génotypes. A $85 \%$ de niveau de similarité, il y avait quatre groupes dont l'un regroupait onze des dix-huit génotypes. Les résultats ont montré une faible diversité génétique au sein de la plante arraignée au Zimbabwé. La plupart des traits agronomiques pourraient affectés par selection directionelle en tenant compte des préférences des producteurs. Certains descripteurs sélectivement neutres tels que la couleur de la tige et du fruit, le nombre de lobules foliaires, l'aspect du fruit et la forme du fruit peuvent être utilisés pour caractériser les accessions de la plantes arraignée.

Mots Clés: Cleome gynandra, descripteur de traits, Zimbabwé 


\section{INTRODUCTION}

Spider plant (Cleome gynandra L.) is a traditional vegetable consumed in several countries in Africa (Chweya, 1997). This traditional vegetable is rich in nutrients that contribute to a healthy diet for many rural Africans, with limited food budgets (Chivinge, 1983; Chweya, 1997; Mishra et al., 2011). The crop has a number of health benefits, which include iron supplementation for treatment of anaemia, muscle pains and chest pains (Chivinge, 1983; Chweya, 1997). In most African countries, the crop is sold on the markets (Onyango et al., 2013) to generate income for the resource-limited farmers.

Spider plant is a diploid plant with a common number of chromosomes of twenty $(2 n=2 x=20)$ (Chweya, 1997). Spider plant is a branched herbaceous, annual herb that can reach up to 1.5 $\mathrm{m}$ high. The stem and leaf stalks have a thick glandular form. Stem colour varies from green to purple. Leaves can be alternate or have leaf loblets originating from one point. One compound leaf can have 3 - 7 leaf loblets. The leaf shape usually varies from obvate to oval. The crop can have sparse or dense pubescence depending on the genotype (Chweya, 1997).

Characterisation and evaluation of spider plant have not been done systematically (Masuka et al., 2012) hence the need for further research. Characterisation will reveal the level of genetic diversity among the collected genotypes of spider plant and guide in their conservation and sustainable use. The aim of this study was to determine the extent of genetic diversity of spider plant based on robust phenotypic markers and understand its implications in the utilisation of spider plant germplasm.

\section{MATERIALS AND METHODS}

A greenhouse experiment was conducted at the Department of Crop Science, University of Zimbabwe. A total of 18 genotypes of spider plant were used. The genotypes were previously collected from all over the country by the University of Zimbabwe and the Horticultural Research Institute. Pots were filled with red clay top soil to a depth of $35 \mathrm{~cm}$, equivalent to $3 \mathrm{~kg}$ of soil. Seeds of 18 genotypes of spider plant were planted using 6 × $3 \alpha$-lattice design, with three replications. Later the plants were thinned to one plant per pot. Compound D fertiliser (7\% N, 14\% $\mathrm{P}$ and $7 \% \mathrm{~K}$ ) was applied as basal dressing at a rate of $300 \mathrm{~kg} \mathrm{ha}^{-1}$, and ammonium nitrate fertiliser $(34.5 \% \mathrm{~N})$ was applied at the same rate as top dressing. The crop was irrigated and hand weeding was done to control the weeds.

Phenotypic traits recorded include stem height, stem colour, stem pubescence, pod number, pod shape and colour, length of pods, presence or absence of pod lining, number of leaf loblets, days to flowering, branch number, leaf fresh mass and leaf dry mass. Stem height was measured from the plant base to the top of plant using a $1.5 \mathrm{~m}$ high calibrated ruler-stick. Stem colour was recorded as green, green with purple nodes, light purple and dark purple. Stem pubescence density was assessed as sparse, intermediate and dense. Pod number was recorded by counting the number of pods per plant. Unripe pod colour was assessed as either green or purple based on visual assessment. Pod shape was recorded as flat, round and bulgy. Pod length was measured from one tip of the pod to the other tip. Pod lining was denoted as either the absence or presence of a purple lining on the pods.

Number of leaf loblets was obtained by counting the number of the loblets that were on each compound leaf. Days to flowering were obtained by counting the number of days from planting up to the time of anthesis. Branch number was obtained by counting the total number of main branches per each genotype. Leaf fresh mass was obtained by weighing freshly harvested leaves per plot using a digital scale. Leaf dry mass was recorded after oven-drying the harvested leaves for 48 hours at $96^{\circ} \mathrm{C}$. Both leaf fresh and dry mass were recorded once after a month when the leaves were ready for harvesting.

Analyses of variance was done on quantitative data using GenStat Software Version 13 (GenStat, 2010). The model was:

$$
Y_{i j k}=r_{i}+b_{j}\left(r_{i}\right)+g_{k}+e_{i j k}
$$

Where: $\mathrm{Y}_{\mathrm{ijk}}$ is the response of the $\mathrm{k}^{\text {th }}$ genotype in the $\mathrm{j}^{\text {th }}$ incomplete block nested with $\mathrm{i}^{\text {th }}$ replication, 
$r_{i}$ is the effect of the $i^{\text {th }}$ replication, $b_{j}\left(r_{i}\right)$ is the effect of the $\mathrm{j}^{\text {th }}$ incomplete block nested within the $\mathrm{i}^{\text {th }}$ replication, $\mathrm{g}_{\mathrm{k}}$ is the effect of the $\mathrm{k}^{\text {th }}$ genotype, and $\mathrm{e}_{\mathrm{ijk}}$ is the random error. The broad sense heritability was estimated as:

$$
\delta^{2} g /\left(\delta^{2} g+\delta^{2} e\right)
$$

Where: $\delta^{2} \mathrm{~g}$ is the genotypic variance component and $\delta^{2} e$ is the error variance component.

The qualitative traits that included presence or absence of pod lining, stem colour, pod shape, number of leaf loblets and stem pubescence were coded into binary data. The binary data were used to form a similarity matrix based on the simple matching rule. The similarity matrix was used in hierarchical cluster analysis to form a dendrogram based on unweighted pair-group method using arithmetic averages (UPGMA) using GenStat Software Version 13 (GenStat, 2010).

\section{RESULTS}

There were no significant differences in days to flowering, branch number, fresh mass, dry mass, pod number and length, and stem height (Table $1)$. The variance component due to error was higher than the genotypic variance component for all quantitative traits (Table 1). This resulted in high coefficients of variation and low broad sense heritability estimates (0-39\%).

The spider plant genotypes showed various stem colours, which included green (genotypes CG01 and CG18), green with purple nodes (genotypes CG03 and CG07), light purple (genotypes CG09 and CG16) and dark purple

TABLE 1. Genotype means and related parameters for 18 spider plant genotypes

\begin{tabular}{|c|c|c|c|c|c|c|c|}
\hline Genotype code & $\begin{array}{l}\text { Days to } \\
\text { flowering }\end{array}$ & $\begin{array}{l}\text { Branch } \\
\text { number }\end{array}$ & $\begin{array}{l}\text { Fresh } \\
\text { mass }(\mathrm{g}) \\
\text { per plot }\end{array}$ & $\begin{array}{l}\text { Dry mass } \\
\qquad(\mathrm{g}) \\
\text { per plot }\end{array}$ & $\begin{array}{c}\text { Pod } \\
\text { number }\end{array}$ & $\begin{array}{c}\text { Pod } \\
\text { length }(\mathrm{cm})\end{array}$ & $\begin{array}{c}\text { Stem } \\
\text { height }(\mathrm{cm})\end{array}$ \\
\hline CG01 & 45.39 & 3.76 & 13.08 & 2.10 & 44.44 & 11.75 & 131.03 \\
\hline CG02 & 42.72 & 5.81 & 6.80 & 0.99 & 22.55 & 7.17 & 70.20 \\
\hline CG03 & 39.13 & 6.16 & 21.76 & 3.28 & 51.42 & 9.75 & 63.65 \\
\hline CG04 & 43.45 & 5.65 & 37.62 & 5.53 & 26.39 & 8.93 & 88.50 \\
\hline CG05 & 47.41 & 7.08 & 12.64 & 2.25 & 32.51 & 7.96 & 114.79 \\
\hline CG06 & 47.57 & 3.66 & 12.53 & 1.34 & 62.21 & 8.82 & 123.47 \\
\hline CG07 & 42.22 & 5.71 & 13.22 & 1.99 & 62.14 & 9.70 & 81.78 \\
\hline CG08 & 37.48 & 6.76 & 20.88 & 3.31 & 36.53 & 7.67 & 98.68 \\
\hline CG09 & 38.68 & 4.76 & 22.21 & 2.84 & 48.83 & 9.40 & 84.45 \\
\hline CG10 & 44.62 & 3.52 & 22.10 & 3.02 & 37.53 & 9.21 & 92.53 \\
\hline CG11 & 36.34 & 5.05 & 23.91 & 3.60 & 61.47 & 11.34 & 82.40 \\
\hline CG12 & 39.21 & 5.39 & 24.18 & 3.40 & 30.53 & 10.49 & 83.23 \\
\hline CG13 & 40.17 & 5.69 & 43.03 & 6.57 & 50.55 & 10.91 & 63.65 \\
\hline CG14 & 46.27 & 4.13 & 22.30 & 3.29 & 5.95 & 9.04 & 99.06 \\
\hline CG15 & 44.98 & 4.68 & 16.18 & 2.44 & 42.34 & 9.05 & 104.41 \\
\hline CG16 & 38.35 & 5.26 & 39.71 & 5.59 & 33.56 & 8.69 & 70.79 \\
\hline CG17 & 44.84 & 5.20 & 20.55 & 3.04 & 20.46 & 9.08 & 93.25 \\
\hline CG18 & 43.50 & 5.40 & 25.60 & 4.17 & 12.58 & 8.11 & 108.45 \\
\hline Grand mean & 42.35 & 5.20 & 22.13 & 3.26 & 37.89 & 9.28 & 91.91 \\
\hline P-value & 0.06 & 0.72 & 0.08 & 0.30 & 0.08 & 0.15 & 0.51 \\
\hline Coefficient of variation (\%) & 7.88 & 26.80 & 37.19 & 46.01 & 48.55 & 15.19 & 27.85 \\
\hline Genotype mean square & 24.04 & 1.47 & 133.52 & 2.90 & 664.60 & 3.22 & 646.10 \\
\hline Error mean square & 11.13 & 1.95 & 67.71 & 2.26 & 338.40 & 1.99 & 655.30 \\
\hline Genotypic variance component & 4.30 & 0.00 & 21.94 & 0.22 & 108.73 & 0.41 & 0.00 \\
\hline Error variance component & 11.13 & 1.95 & 67.71 & 2.26 & 338.40 & 1.99 & 655.30 \\
\hline Broad sense heritability (\%) & 38.66 & 0.00 & 32.40 & 9.59 & 32.13 & 20.69 & 0.00 \\
\hline
\end{tabular}


(genotype CG11). The genotypes showed some observable variations in stem pubescence, which were distinctly grouped into three categories, namely sparse, intermediate and dense pubescence. Pubescence was sparse in genotypes CG02 and CG10, intermediate in CG05, CG07, CG12, CG14 and CG15. The rest of genotypes had dense pubescence.

The shape of the pods varied from flat to round and bulgy. There was, also variation in pod colour, ranging from green to purple. There were variations in the presence of a purple lining on the pods among the genotypes. Purple linings on pods were observed on genotypes CG04, CG09, CG11 and CG16; while the rest had no such a lining. Variations were observed in number of leaf loblets, with 7 leaf loblets in genotypes CG01, CG05 and CG15 and the rest with 5 loblets.

All quantitative traits were statistically nonsignificant so they were not included in cluster analysis because they would not discriminate. A dendrogram was drawn based on the qualitative traits that included stem colour, presence or absence of pod lining, number of leaf loblets, pod shape and colour, and stem pubescence (Fig. 1). The dendrogram showed that at $70 \%$ similarity level, all the genotypes belonged to one cluster. At $85 \%$ similarity level, four clusters were identified. Cluster one had genotype CG05, cluster two had genotype CG11, and cluster three

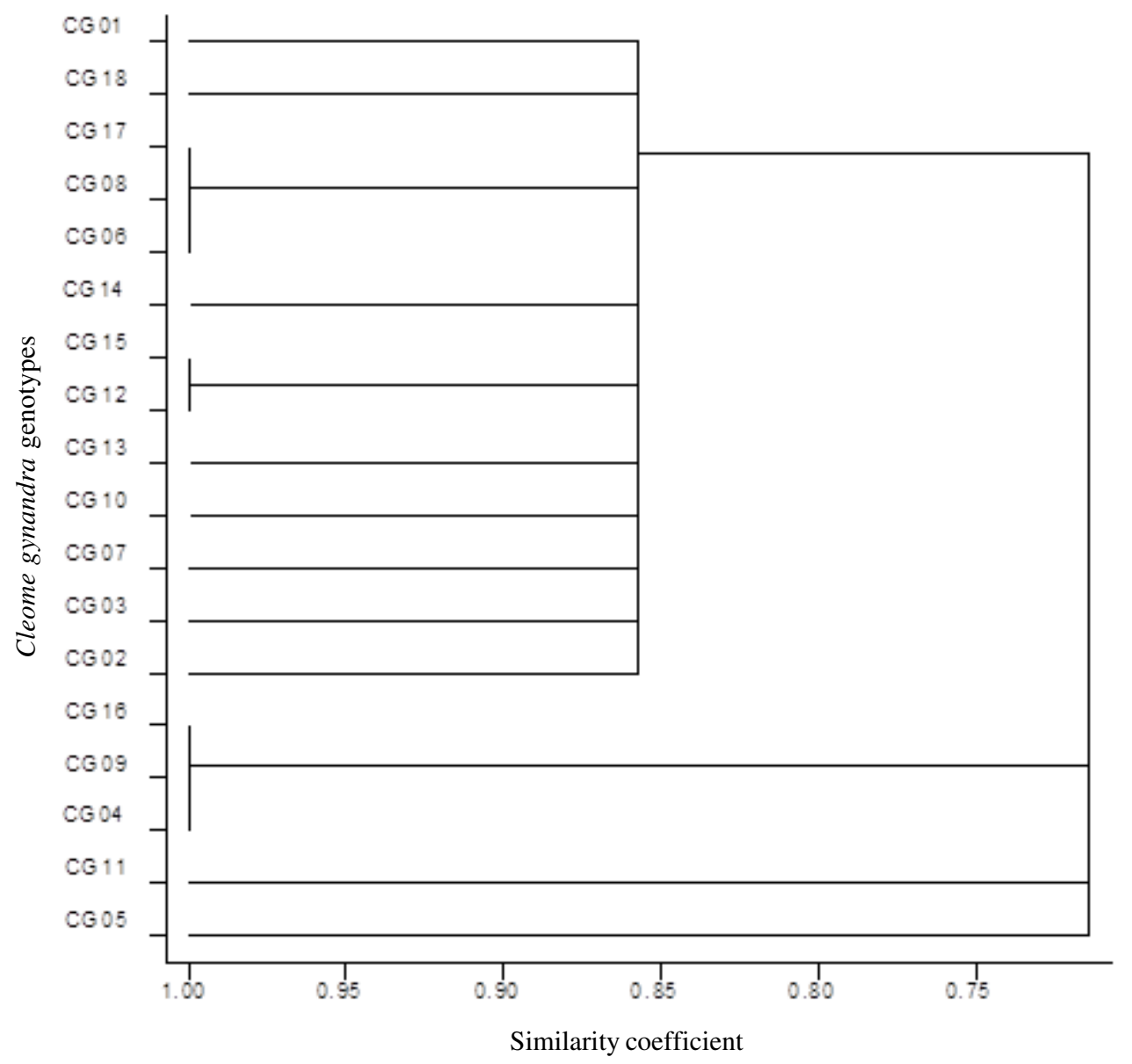

Figure 1. A dendrogram of spider plant genotypes based on simple matching coefficients distance with clustering based on unweighted pair-group method using arithmetic averages. 
had genotypes CG09, CG04 and CG16. The fourth cluster had the largest number of genotypes (eleven out of sixteen) (Fig. 1).

\section{DISCUSSION}

Absence of significant differences (Table 1) among the seven quantitative traits shows that genetic diversity among the spider plant genotypes is low. This is evidenced by the low genotypic variance components for all traits observed that resulted in very low broad sense heritability values. Low heritability values indicate that genetic variation was negligible. Low genetic diversity is further supported by the clustering pattern of genotypes in which all genotypes had at least $70 \%$ similarity. Furthermore, at $85 \%$ similarity level, about eleven genotypes remained in the same cluster (Fig. 1). This shows that a huge proportion of spider plant germplasm in the country is highly related. Masuka et al. (2012) observed low genetic diversity of this crop while working with a sub-sample (three) of these genotypes in Zimbabwe.

Genetic relatedness among germplasm present a huge challenge in future utilisation of such resources (Gepts, 2006). A small genetic diversity means that the entire population can succumb to natural calamities such as biotic and abiotic stresses (Gepts, 2006). Domestication coupled to the reproductive mode of this species could have resulted into narrow genetic diversity of spider plant. In southern Africa, spider plants grow in the disturbed agricultural lands (Chivinge, 1983). In those fields, farmers weed the crop, and leave only a few plants from which the seed of the next generation will be derived. This reduces the effective population size, leading to population bottlenecks and the founder effect (Whitaker, 2004).

Human activities are the major causes of genetic erosion in many crops. Low genetic diversity in spider plant could also be due to the reproductive mode of this crop that encourages self-pollination and thus reduced diversity. Nonrandom mating means that there is limited chance to reproduce in a manner that maintains the genetic diversity within populations (Whitaker, 2004).
Selection approaches have greatly affected genetic diversity of several crops (Whitaker, 2004). Farmers unintentionally select genotypes that give them the best. This unintentional selection comes about as farmers weed their fields, and leave only a few parent plants to perpetuate the next generation. The general trend in domesticated plants is that, farmers and breeders make directional selection. In this regard, genetic diversity for most agronomic traits would be greatly reduced in the same manner across regions.

The variation observed on stem colour is in agreement with findings by Chweya (1997) that spider plant genotypes range from green to purple, with intensity of stem pigmentation varying from light to deep purple. The dense stem pubescence observed on many genotypes could be a natural mechanism to defend themselves against pests (Chivinge, 1983; Chweya, 1997). Stem pubescence deters pests such as the aphids.

Pod colour is easy to use in distinguishing genotypes, since it has only two extreme classes. Leaf loblets number observed in this study showed little variation since there were only two groups of seven and six leaf loblets. This little variation was also observed by Masuka et al. (2012). However, two decades ago, Chweya (1997) noted that spider plant can have a wider range of leaf loblets that range from three to seven. These show evidence of loss of genetic diversity in spider plant germplasm and hence plant breeders and farmers should conserve the remaining germplasm.

A few qualitative traits showed some variations that accounted for less than $30 \%$ dissimilarity observed on the dendrogram (Fig. 1). Such traits are selectively neutral because they do not have economic value. In this regard, such trait variations have been accumulated in the spider plant genotypes. These qualitative traits are common in Africa and have been widely reported in Kenya (K'opondo, 2011). Such traits are easy to score and remember and thus should be used as robust discriminating phenotypic markers for cultivar description and identification. For example, Kutsukutsa et al. (2014) reported some spider plant genotypes that had low levels in $\beta$-glycosides, yet farmers struggled to identify 
them. To reduce the bitterness, farmers boiled their spider plant for long with a huge penalty in loss of thermo labile nutrients such as vitamins (Kutsukusta et al., 2014). If farmers are taught how to use some of these robust discriminating traits, they can identify genotypes with low bitterness, reduce the boiling and save nutrients.

\section{CONCLUSION}

Little genetic diversity (30\% dis-similarity) exists among spider plant genotypes. Some selectively neutral, robust descriptor traits such as colour of the stem and pods, leaf loblets number, pod lining and pod shape can be used in characterisation and distinguishing spider plant genotypes.

\section{ACKNOWLEDGEMENT}

We are grateful to the funding from the International Foundation for Science.

\section{REFERENCES}

Chivinge, A. 1983. A weed survey of arable lands in the commercial sector of Zimbabwe. Zimbabwe Agricultural Journal 80:139-141.

Chweya, J.A. 1997. Genetic enhancement of indigenous vegetables in Kenya. Traditional African Vegetables. International Plant Genetic Resources Institute (IPGRI), Rome, Italy. pp. 86-95.
Gepts, P. 2006. Plant genetic resources conservation and utilisation. Crop Science 46:2278-2292.

K'Opondo, F. 2011. Morphological characterisation of selected spider plant (Cleome gynandra L.) types from western Kenya. Annals of Biological Research 2:5464.

Kutsukutsa, R., Gasura, E., Mabasa, S. and Ngadze, E. 2014. Variability in condensed tannins and bitterness in spider plant genotypes. African Crop Science Journal 22:275-280.

Masuka, A., Goss, M. and Mazarura, U. 2012. Morphological characterisation of four selected spider plant (Cleome gynandra L.) morphs from Zimbabwe and Kenya. Asian Journal of Agriculture and Rural Development 2:646-657.

Mishra, S., Moharana, S. and Dash, M. 2011. Review on Cleome gynandra. International Journal Pharmaceutical Chemistry 1:681689.

Onyango, C.M., Kunyanga, C.N., Ontita E. G., Narla, R.D. and Kimenju, J.W. 2013. Current status on production and utilisation of spider plant (Cleome gynandra L.) an underutilised leafy vegetable in Kenya. Genetic Resources and Crop Evolution 60: 2183-2189.

Whitaker, K. 2004. Non-random mating and population genetic subdivision of two broadcasting corals at Ningaloo Reef, Western Australia. Marine Biology 144: 593603. 